medRxiv preprint doi: https://doi.org/10.1101/2020.11.23.20237404; this version posted December 2, 2020. The copyright holder for this preprint (which was not certified by peer review) is the author/funder, who has granted medRxiv a license to display the preprint in It is made available under a CC-BY-NC-ND 4.0 International license .

\title{
A COVID-19 transmission model informing medication development and supply chain
} needs

Annabelle Lemenuel-Diot ${ }^{1 *}$, Barry Clinch ${ }^{2}$, Aeron C. Hurt ${ }^{3}$, Paul Boutry ${ }^{3}$, Johann Laurent ${ }^{1}$, Mathias Leddin ${ }^{1}$, Stefan Frings ${ }^{3}$ and Jean Eric Charoin ${ }^{3}$

${ }^{1}$ Roche Innovation Center, Basel, Switzerland; ${ }^{2}$ Roche Products Ltd, Welwyn Garden City, United Kingdom; ${ }^{3}$ F. Hoffmann-La Roche Ltd, Basel, Switzerland

\section{*Author for correspondence:}

Annabelle Lemenuel-Diot

Email: annabelle.lemenuel@roche.com

Word count: 3101

Tables/figures: 2 tables and 5 figures

References: 40

Keywords (1-5 mandatory from prespecified list): COVID-19, infectious disease epidemiology, mathematical modelling, pandemic, SIR model 
medRxiv preprint doi: https://doi.org/10.1101/2020.11.23.20237404; this version posted December 2, 2020. The copyright holder for this preprint (which was not certified by peer review) is the author/funder, who has granted medRxiv a license to display the preprint in

It is made available under a CC-BY-NC-ND 4.0 International license .

\begin{abstract}
Accurate prediction of COVID-19 cases can optimize clinical trial recruitment, inform mitigation strategies and facilitate rapid medication development. Here we present a countryspecific, modified Susceptible, Exposed, Infectious, Removed (SEIR) model of SARS-CoV-2 transmission using data from the Johns Hopkins University COVID-19 Dashboard. Intercountry differences in initial exposure, cultural/environmental factors, reporting requirements and stringency of mitigation strategies were incorporated. Asymptomatic patients and superspreaders were also factored into our model. Using these data, our model estimated $65.8 \%$ of cases as asymptomatic; symptomatic and asymptomatic people were estimated to infect 2.12 and 5.83 other people, respectively. An estimated $9.55 \%$ of cases were super-spreaders with a 2.11-fold higher transmission rate than average. Our model estimated a mean maximum infection rate of 0.927 cases/day (inter-country range, $0.63-1.41$ ) without mitigation strategies. Mitigation strategies with a stringency index value of $\geq 60 \%$ were estimated to be required to reduce the reproduction ratio below 1 . It was predicted that cases over the next 2 months would differ between countries, with certain countries likely to experience an accelerated accumulation of cases. Together, results from our model can guide distribution of diagnostic tests, impact clinical trial development, support medication development and distribution and inform mitigation strategies to reduce COVID-19 spread.
\end{abstract}


medRxiv preprint doi: https://doi.org/10.1101/2020.11.23.20237404; this version posted December 2, 2020. The copyright holder for this preprint (which was not certified by peer review) is the author/funder, who has granted medRxiv a license to display the preprint in It is made available under a CC-BY-NC-ND 4.0 International license .

\section{Key Findings}

- Predicting COVID-19 cases can inform medication development and mitigation strategies

- We created a modified SEIR model of SARS-CoV-2 transmission

- We integrated asymptomatic cases, super-spreaders and hotspots that drive viral spread

- Mitigation strategies with a stringency index of $\geq 60 \%$ are required to reduce the $R R$ below 1

- Some countries may experience an accelerated accumulation of cases in the coming months 
medRxiv preprint doi: https://doi.org/10.1101/2020.11.23.20237404; this version posted December 2, 2020. The copyright holder for this preprint (which was not certified by peer review) is the author/funder, who has granted medRxiv a license to display the preprint in It is made available under a CC-BY-NC-ND 4.0 International license .

\section{Introduction}

As of 25 October 2020, the coronavirus disease 2019 (COVID-19) first reported in Wuhan, China, in December 2019 had resulted in 43 million confirmed cases globally, with infections continuing to spread [1]. This unprecedented pandemic has presented unique challenges for medical professionals, biomedical researchers, governmental and non-governmental organizations and members of the pharmaceutical industry, each of whom have shown an unwavering commitment to patient care and support [2,3]. Specifically, the pharmaceutical industry has increased efforts to research, develop, register and make available solutions ranging from antivirals to treatments of complications of COVID-19 in record speed while also carefully managing supply lines and manufacturing sites for existing medications in high demand for the general management of patients with COVID-19 [4].

To support clinical trial recruitment, medication development, medication supply and distribution strategies, it is vital for the pharmaceutical industry, national and multi-national organizations, governments and non-governmental organizations to understand the epidemiological concept of virus transmission, the patterns and implications of severe acute respiratory syndrome coronavirus 2 (SARS-CoV-2) viral spread and the impact of different non-pharmaceutical interventions (NPIs) proposed as mitigation strategies on local, national and international levels $[5,6]$. Specifically, the ability to accurately project the number of expected cases in each country over time could assist in selecting clinical trial sites with good potential for rapid patient recruitment and medication development. Furthermore, this information could guide the fair and equitable distribution of diagnostic tests, treatment options and vaccines. 
medRxiv preprint doi: https://doi.org/10.1101/2020.11.23.20237404; this version posted December 2, 2020. The copyright holder for this preprint (which was not certified by peer review) is the author/funder, who has granted medRxiv a license to display the preprint in It is made available under a CC-BY-NC-ND 4.0 International license .

The basic reproduction number $\left(\mathrm{R}_{0}\right)$ for SARS-CoV-2 infection before the implementation of mitigation strategies is estimated to range from approximately 2.0 to 3.6 [7-12], with a high risk for transmission because of high numbers of asymptomatic subjects and emerging clusters [13-15]. Transmission models based on real-world epidemiological data are important tools for understanding the dynamics of SARS-CoV-2 transmission and can be useful to guide mitigation strategies and policy decisions designed to assist patients with COVID-19 and reduce disease spread [9, 16-21].

Mitigation strategies with NPIs have been effective in helping to curb the spread of SARS$\mathrm{CoV}-2$ and in reducing the reproduction ratio $(\mathrm{RR})[12,22]$, though these are likely hindered by the relatively high proportion of asymptomatic cases of COVID-19 [15, 23, 24]. Although the magnitude of infectiousness in asymptomatic patients (i.e. when the infector has no symptoms throughout the course of the disease) is difficult to quantify, these cases are expected to heavily impact transmission dynamics $[25,26]$. Indeed, non-peer-reviewed mathematical modelling studies highlight the importance of accounting for asymptomatic persons when describing transmission dynamics [27, 28]. As such, this analysis could support public health considerations and suggest, by quantifying their contributions, that asymptomatic persons might be major drivers of the COVID-19 pandemic. Unless asymptomatic persons happen to get tested, they may continue to socialize and work during the entire infectious period, in contrast to situations in which the vast majority of people are symptomatic and can be identified without testing and for whom rapid quarantine is possible.

Although some components of viral transmission (e.g. proportions of asymptomatic and “super-spreader" cases, duration of latency, pre-symptomatic infectious and postsymptomatic infectious periods and duration of infectiousness) are likely to be consistent 
medRxiv preprint doi: https://doi.org/10.1101/2020.11.23.20237404; this version posted December $2,2020$. The copyright holder for this preprint (which was not certified by peer review) is the author/funder, who has granted medRxiv a license to display the preprint in

It is made available under a CC-BY-NC-ND 4.0 International license.

across countries, other components affecting patterns of viral spread are expected to differ between countries, further complicating potential models of viral transmission. Further, cases of COVID-19 are not uniformly distributed within a country; rather, they are primarily located in "hotspots" of various sizes that, without mitigation, merge and grow, potentially including the entire population [29-31]. A proportion of super-spreaders has also been reported in the COVID-19 population, and a limitation of classical models is the use of mean parameter values across the population, even though different persons may have different disease characteristics (e.g. viral load, infection rate, duration of symptoms). Additional proposed modelling approaches could account for super-spreader profiles by differentiating this type of case and estimating specific transmission characteristics of super-spreaders.

Although several epidemiological transmission models exist, our model is the first to clearly quantify the effect of NPIs on COVID-19 transmission in individual countries while also accounting for the expected contribution of asymptomatic cases to COVID-19 transmission and differentiating potential super-spreaders. Given that these components are crucial for robust, country-specific projections, we aimed to implement a modified Susceptible, Exposed, Infectious, Removed (SEIR) model of SARS-CoV-2 transmission incorporating those components, with the objectives of supporting the development of medications, optimizing clinical trial recruitment and facilitating a fast-to-market strategy for medications that have the potential to reduce symptoms and complications in patients with COVID-19.

\section{Methods}

\section{Data sources}

Real-world epidemiological data were obtained from the Johns Hopkins University COVID19 Center for Systems Science and Engineering COVID-19 Dashboard on 31 August 2020 
medRxiv preprint doi: https://doi.org/10.1101/2020.11.23.20237404; this version posted December 2, 2020. The copyright holder for this preprint (which was not certified by peer review) is the author/funder, who has granted medRxiv a license to display the preprint in It is made available under a CC-BY-NC-ND 4.0 International license .

[1]. This includes data from national and state government health departments and local media reports. In addition, country-level mitigation data from the Coronavirus Government Response Tracker, collected and validated by Oxford University [32], were used to investigate the potential mitigation impact of NPIs on the transmission of SARS-CoV-2, with the objective of building country-specific quantitative relationships between NPIs and transmission model parameters.

\section{Model development}

Development of the initial modified SEIR model was based on the susceptible population (S), exposed patients not yet infectious (E), infected infectious patients who are asymptomatic (Ia), infected infectious patients (I), recovered patients (R) and death (D) (Fig. 1). Additional components, detailed below, were added to account for reporting rates of individual countries, incorporate hotspots and emerging clusters, include asymptomatic and superspreader profiles and evaluate the impact of various mitigation strategies on transmission rate. The model was used to estimate the expected total number of symptomatic and asymptomatic cases regardless of whether they were reported.

To account for regional differences in initial exposure, we started with a set time of 1 January 2020 and estimated a country-specific lag time to the first infected cases in each country. To forecast accurately, it was essential to properly incorporate the population at risk for infection in each country and to avoid overestimating or underestimating the transmission rate because this could impact the model's outcomes and ultimately misinform subsequent decisions regarding medication development and deployment. To account for non-uniform geographical distribution of cases within a country, the size of a susceptible population was 
medRxiv preprint doi: https://doi.org/10.1101/2020.11.23.20237404; this version posted December 2, 2020. The copyright holder for this preprint (which was not certified by peer review) is the author/funder, who has granted medRxiv a license to display the preprint in It is made available under a CC-BY-NC-ND 4.0 International license.

initially estimated by mimicking the size and distribution of COVID-19 hotspots and was inflated every 15 days using an estimation of the inflation parameter for that country.

The asymptomatic population was included in our SEIR model by estimating the proportion of asymptomatic cases and assuming a daily infection rate of half that of symptomatic cases. This rate assumption was based on reports of reduced viral load in asymptomatic persons, a potential surrogate marker of the infection rate $[23,33,34]$. The infectious period of asymptomatic cases was fixed at 10 days, based on the observed viral load time course [23, 33]. These characteristics of asymptomatic cases were then further refined using sensitivity analysis. The super-spreaders were accounted for in our SEIR model in the same way asymptomatic cases were. However, both the proportion of super-spreaders in the population and the increase in their infection rate could be estimated in our model.

The effect of mitigation strategies on the RR (number of new cases per subject during the entire infectious period) was evaluated using the Oxford COVID-19 Government Response Tracker [32], which calculates a stringency index to score the strength of mitigations. This tool systematically collects country-specific policy responses to COVID-19, including indicators such as school closures and travel restrictions (Fig. 2). The value of an index on any given day is calculated as the average of nine sub-indices pertaining to individual policy indicators assigned a value between 0 and 100, where the stronger the mitigation, the higher the stringency index. In our model, the relationship between the stringency index and the daily infection rate was characterized using an Emax model from which a maximum infection rate could be estimated considering no mitigation (stringency index of 0 ), and then a decrease in the infection rate could be estimated depending on the stringency index, the magnitude of the decrease and the stringency index value that would correspond to $50 \%$ of the decrease. 
medRxiv preprint doi: https://doi.org/10.1101/2020.11.23.20237404; this version posted December 2, 2020. The copyright holder for this preprint (which was not certified by peer review) is the author/funder, who has granted medRxiv a license to display the preprint in

It is made available under a CC-BY-NC-ND 4.0 International license.

We also assumed a similar relationship between the stringency index and the daily infection rate for symptomatic and asymptomatic cases, considering that different NPIs constituting the stringency index (e.g. school or public transport closing) would impact both infection rates. The policy most specific to symptomatic cases is to quarantine starting soon after the emergence of symptoms; we included this in the model as directly impacting the infectious period of symptomatic cases only.

\section{Between-country variability}

Because our objective was to describe and forecast the number of cases in each country, we had to consider which parameters would be similar across countries (virus specific) and which parameters would vary between countries (country specific). Therefore, we included a certain amount of inter-country variability in our model to account for country-specific factors, among them potential differences in transmission resulting from cultural and environmental differences and differences in the way cases were reported. Similarly, the impact of mitigation strategies on the rate of transmission was considered country specific.

\section{Simulations}

Our model was used to project the mid- to long-term expected number of cases in each country according to different scenarios. We fixed the stringency index at the latest reported value for each country at the cut-off date (25 October 2020) because it appeared to reflect the maximum sustainable mitigations countries could implement without jeopardizing economic factors. However, different scenarios could account for specific viral spreading according to the size of the target population (to mimic the occurrence of new clusters). We defined two possible scenarios. In scenario 1, which corresponds to low viral spread, the susceptible population was increased every 15 days using country-specific means of the stringency index 
medRxiv preprint doi: https://doi.org/10.1101/2020.11.23.20237404; this version posted December $2,2020$. The copyright holder for this preprint (which was not certified by peer review) is the author/funder, who has granted medRxiv a license to display the preprint in

It is made available under a CC-BY-NC-ND 4.0 International license.

values estimated during the period with strong travel limitations (mid-March to mid-May). Scenario 2 corresponds to high viral spread with a bi-weekly increase of the susceptible population implemented using country-specific means of the stringency index values estimated over the recent months with no travel restrictions (mid-August to mid-October).

We limited the simulation period to 2 months as we considered the effects of certain parameters (e.g. seasonality of virus transmission, effects of face mask wearing, test strategy, increase in reporting rate due to test deployment) sufficiently ambiguous to limit confidence in a longer simulation period.

\section{Results}

Tailored model for understanding virus spread characteristics per country

Parameter estimates are shown in Table 1. Across countries, our model estimated that it takes an average of 3.43 days after a person contracts the virus to become infectious and another 2.57 days before the onset of symptoms, resulting in an incubation period of almost 6 days. On average, $65.8 \%$ of all cases are estimated to be asymptomatic and $9.55 \%$ of all cases are estimated to be super-spreaders, with a transmission rate 2.11 -fold higher than average.

The stringency index, derived from the Oxford COVID-19 Government Response Tracker [32], was used for scoring initiated mitigations. In our model, the maximum infection rate in the absence of specific policies (other than self-imposed quarantine in response to symptoms) was estimated as 0.927 cases per subject per day of symptoms, with a range between 0.63 and 1.41 , depending on the country. Assuming a reduction in the infection rate of $50 \%$ for presymptomatic and asymptomatic cases, the average RR was computed as shown in Table 2. Based on this, a symptomatic person is predicted to infect a total of 2.12 people - 
medRxiv preprint doi: https://doi.org/10.1101/2020.11.23.20237404; this version posted December $2,2020$. The copyright holder for this preprint (which was not certified by peer review) is the author/funder, who has granted medRxiv a license to display the preprint in It is made available under a CC-BY-NC-ND 4.0 International license .

approximately 1.1 during the pre-symptomatic period and 1.0 during the symptomatic period. An asymptomatic person is predicted to infect 5.83 people in total. Accounting for the proportion of asymptomatic cases estimated by the model, it can be derived that asymptomatic persons are responsible for $84 \%$ of new infections. Thus, the relationship between the stringency index and the daily infection rate could be estimated within the model; an example based on global level data is shown in Fig. 3. A stringency index value of $35.3 \%$ was estimated as required to result in a $50 \%$ decrease in daily infection rate with a range between $17.4 \%$ and $74.5 \%$, depending on the country. Therefore, the stringency index must exceed $60 \%$ to result in the RR in symptomatic cases dropping below 1 (Fig. 3).

Most of the parameters were well estimated. Data fitting to describe the observed cumulative cases are shown in Fig. 4 for representative countries and in the online supplementary appendix for all countries examined. Between-country differences observed in cumulative cases over time were well captured with the model and could be explained by changes in the stringency index and the potential geographic spread of the virus, which are the two timedependent variables in the model.

\section{Supporting questions around clinical development and future supply}

The simulation was also able to illustrate the projection of expected cases for the next 2 months (Fig. 5). These projections may help inform clinical operation considerations with regards to site location for new COVID-19 clinical trials and allow for companies to anticipate future demands for medications and prioritize supplies in territories with the highest current or future needs. For each of the scenarios tested, some countries, such as Russia and Peru, are likely to have more accelerated accumulations of cases than other counties, such as France and the United Kingdom, especially as travel restrictions are put in 
medRxiv preprint doi: https://doi.org/10.1101/2020.11.23.20237404; this version posted December $2,2020$. The copyright holder for this preprint (which was not certified by peer review) is the author/funder, who has granted medRxiv a license to display the preprint in

It is made available under a CC-BY-NC-ND 4.0 International license.

place in countries with slower accumulations of cases. The ability to predict where this acceleration will occur may allow for a more appropriate selection of clinical trial sites for new COVID-19 medications and may increase patient participation in these clinical trials. This, in turn, will ensure that medications that are safe and effective can be rapidly distributed to the patients who need them. Such simulation results, if regularly revised, could also allow for increased availability of medications where the need is likely to be high while also identifying countries that may be less relevant targets.

\section{Discussion}

The objective of this analysis was to tailor a transmission model to address the current issues faced by pharmaceutical companies, governments and multi-national organizations: how to best identify countries that can facilitate faster and more efficient development of potential COVID-19 therapies, with the ultimate goal of getting potentially life-saving medications to those in need. The model presented here has the potential to help support the selection of clinical trial sites, the initiation of mitigation strategies and the distribution of COVID-19 diagnostics, treatments and vaccines.

This modelling study of COVID-19 transmission, based on total global cases reported as of 25 October 2020, demonstrated disease model parameters consistent with those that have been reported in the literature, such as an incubation period of 6 days [35, 36][37]. In addition, our model was able to estimate similar rates of asymptomatic cases and proportions of super-spreaders across all countries. The estimated proportion of asymptomatic cases $(66 \%)$ is very close to other reported values in the literature $[15,23,38]$. In addition, the estimated proportion of super-spreaders identified here (almost 10\%) is similar to the expected proportion identified in other studies [39]. According to their daily infection rate, 
medRxiv preprint doi: https://doi.org/10.1101/2020.11.23.20237404; this version posted December $2,2020$. The copyright holder for this preprint (which was not certified by peer review) is the author/funder, who has granted medRxiv a license to display the preprint in It is made available under a CC-BY-NC-ND 4.0 International license .

super-spreaders are expected to infect 3.11 times the number of people normal spreaders infect. In the absence of mitigation, this would lead to one symptomatic super-spreader infecting approximately 6.6 people and one asymptomatic super-spreader infecting almost 11 people, highlighting the large contribution this small proportion of people can make to virus transmission, which is consistent with previous reports [40]. Furthermore, our model confirms that most new cases result from asymptomatic transmission, occurring either during the pre-symptomatic period (from persons who later become symptomatic) or from asymptomatic persons $[27,28]$. In general, these data highlight the importance of incorporating asymptomatic persons in transmission models to obtain more accurate projections of future cases.

To better describe country-specific data, identify which countries are likely to experience large numbers of emerging cases and help inform decisions surrounding future clinical trial locations, our strategy incorporated inter-country variability into the model. This variability was considered for parameters that may differ, depending on social, cultural and societal factors (such as the rate of infection and the strength of NPIs), allowing for appropriate country-specific forecasts. These parameters could indirectly account for the number of contacts each person may have (e.g. household context, place of work) and the level of adherence to NPIs, with an effect that could differ between countries despite a similar stringency index. Notably, the amplitude of the inter-country variability was large, suggesting large heterogeneity between countries.

With this model, we were able to simulate the expected number of COVID-19 cases over time using different scenarios of mitigation. Our model can be used to project the future profile of the pandemic based on current data to investigate the effect of mitigation specific to 
medRxiv preprint doi: https://doi.org/10.1101/2020.11.23.20237404; this version posted December $2,2020$. The copyright holder for this preprint (which was not certified by peer review) is the author/funder, who has granted medRxiv a license to display the preprint in It is made available under a CC-BY-NC-ND 4.0 International license.

each country. It also allows for the simulation of potential new clusters though a countryspecific stringency index (i.e. last stringency index carried forward in the simulation), accounting for an increase in the target population over time based on country-level estimates. Together these data can provide important information for the identification of promising new sites for COVID-19 clinical trials and may help support global supply chain networks by identifying potential supply-and-demand challenges arising in different countries during the pandemic.

Our model does have certain limitations. First, it was based on observed infected cases.

Given that some patients are asymptomatic or show only mild symptoms, however, it is likely that the true number of cases is higher than captured here. In addition, changes in the reporting rate because of local testing policies and potential seasonality differences are not incorporated or investigated in this model. As data on these factors are gathered over time, it may be possible to integrate them into our model to support future forecasting. Nevertheless, it is worth noting that this model has remained relatively stable since September 2020, with bi-weekly updates only minimally impacting the forecasting results. Finally, the model does not account for the availability of a vaccine. When an efficacious vaccine is widely available, our model must be adjusted to account for the reduced size of the susceptible population and the limited possibility of transmission. As with all predictive models, additional data on each of these factors will improve our understanding of SARS-CoV-2 transmission; integrating these data into our model can support more accurate forecasting in the future.

In summary, our model can support and inform the development of clinical trials and the supply and distribution of future medications. By updating and adjusting the model as new data are received, our model could potentially inform longer-term considerations as well. 
medRxiv preprint doi: https://doi.org/10.1101/2020.11.23.20237404; this version posted December 2, 2020. The copyright holder for this preprint (which was not certified by peer review) is the author/funder, who has granted medRxiv a license to display the preprint in It is made available under a CC-BY-NC-ND 4.0 International license .

Finally, our model also represents a possible framework for describing transmission characteristics of other diseases, estimating viral spread and refining country-specific estimates of disease impact. 
medRxiv preprint doi: https://doi.org/10.1101/2020.11.23.20237404; this version posted December 2, 2020. The copyright holder for this preprint (which was not certified by peer review) is the author/funder, who has granted medRxiv a license to display the preprint in It is made available under a CC-BY-NC-ND 4.0 International license .

\section{Acknowledgements}

Third-party editorial assistance was provided by Sara Duggan, $\mathrm{PhD}$, and Stacie Dilks, $\mathrm{PhD}$, of ApotheCom and was funded by F. Hoffmann-La Roche Ltd.

\section{Author contributions and degree of contribution}

Conceptualization and writing review and editing: $\mathrm{PB}, \mathrm{JEC}, \mathrm{BC}, \mathrm{SF}$ and $\mathrm{AH}$; data curation: ML; formal analysis: ALD; investigation: PB; methodology: ALD, PB and JEC; resources: ML; software: JL; supervision: JEC.

\section{Financial support}

This study was funded by F. Hoffmann-La Roche Ltd.

\section{Conflict of interest}

ALD, JL and ML are employees of Roche Pharmaceuticals, Inc., and receive salary and stock options. BC is an employee of Roche Products Ltd and receives salary and stock options. $\mathrm{ACH}, \mathrm{PB}, \mathrm{SF}$ and JEC are employees of F. Hoffmann-La Roche Ltd and receive salary and stock options.

\section{Data availability statement}

Qualified researchers may request access to individual patient level data through the clinical study data request platform (https://vivli.org/). Further details on Roche's criteria for eligible studies are available here (https://vivli.org/members/ourmembers/). For further details on Roche's Global Policy on the Sharing of Clinical Information and how to request access to related clinical study documents, see here 
medRxiv preprint doi: https://doi.org/10.1101/2020.11.23.20237404; this version posted December 2, 2020. The copyright holder for this preprint (which was not certified by peer review) is the author/funder, who has granted medRxiv a license to display the preprint in It is made available under a CC-BY-NC-ND 4.0 International license

(https://www.roche.com/research_and_development/who_we_are_how_we_work/clinical_tri als/our_commitment_to_data_sharing.htm). 
medRxiv preprint doi: https://doi.org/10.1101/2020.11.23.20237404; this version posted December 2, 2020. The copyright holder for this preprint (which was not certified by peer review) is the author/funder, who has granted medRxiv a license to display the preprint in It is made available under a CC-BY-NC-ND 4.0 International license .

\section{References}

1. Johns Hopkins University (2020) COVID-19 Dashboard by the Center for Systems Science and Engineering (CSSE) at Johns Hopkins University (JHU). https://coronavirus.jhu.edu/map.html. Accessed November 12, 2020.

2. Ayati N, Saiyarsarai P and Nikfar S (2020) Short and long term impacts of COVID19 on the pharmaceutical sector. DARU Journal of Pharmaceutical Sciences 1-7.

3. Asaad M, Habibullah NK and Butler CE (2020) The impact of COVID-19 on clinical trials. Annals of Surgery 272, e222-e223.

4. Kelleher K et al. (2020) Pharma operations: the path to recovery and the next normal. https://www.mckinsey.com/industries/pharmaceuticals-and-medical-products/ourinsights/pharma-operations-the-path-to-recovery-and-the-next-normal\#. Accessed November 12, 2020.

5. Centers for Disease Control and Prevention (2020) COVID-19 mathematical modeling. https://www.cdc.gov/coronavirus/2019-ncov/covid-data/mathematicalmodeling.html. Accessed November 12, 2020.

6. Buchwald AG et al. (2020) Infectious disease transmission models to predict, evaluate, and improve understanding of COVID-19 trajectory and interventions. Annals of the American Thoracic Society 17, 1204-1206.

7. Lemaitre JC et al. (2020) Assessing the impact of non-pharmaceutical interventions on SARS-CoV-2 transmission in Switzerland. Swiss Medical Weekly 150, w20295.

8. Davies NG et al. (2020) Effects of non-pharmaceutical interventions on COVID-19 cases, deaths, and demand for hospital services in the UK: a modelling study. The Lancet Public Health 5, E375-E385.

9. Zhu Y and Chen YQ (2020) On a statistical transmission model in analysis of the early phase of COVID-19 outbreak. Statistics in Biosciences 1-17. 
medRxiv preprint doi: https://doi.org/10.1101/2020.11.23.20237404; this version posted December 2, 2020. The copyright holder for this preprint (which was not certified by peer review) is the author/funder, who has granted medRxiv a license to display the preprint in It is made available under a CC-BY-NC-ND 4.0 International license .

10. Wu JT, Leung K and Leung GM (2020) Nowcasting and forecasting the potential domestic and international spread of the 2019-nCoV outbreak originating in Wuhan, China: a modelling study. Lancet 395, 689-697.

11. Li Q et al. (2020) Early transmission dynamics in Wuhan, China, of novel coronavirusinfected pneumonia. The New England Journal of Medicine 382, 1199-1207.

12. Gatto M et al. (2020) Spread and dynamics of the COVID-19 epidemic in Italy: effects of emergency containment measures. Proceedings of the National Academy of Sciences of the United States of America 117, 10484-10491.

13. Tan J et al. (2020) Transmission and clinical characteristics of asymptomatic patients with SARS-CoV-2 infection. Future Virology 15, 10.2217/fvl-2020-0087.

14. Leclerc QJ et al. (2020) What settings have been linked to SARS-CoV-2 transmission clusters? Wellcome Open Research 5, 83.

15. Oran DP and Topol EJ (2020) Prevalence of asymptomatic SARS-CoV-2 infection: a narrative review. Ann Intern Med 173, 362-367.

16. Prem K et al. (2020) The effect of control strategies to reduce social mixing on outcomes of the COVID-19 epidemic in Wuhan, China: a modelling study. The Lancet Public Health 5, e261-e270.

17. Hellewell J et al. (2020) Feasibility of controlling COVID-19 outbreaks by isolation of cases and contacts. The Lancet Global Health 8, e488-e496.

18. Chinazzi M et al. (2020) The effect of travel restrictions on the spread of the 2019 novel coronavirus (2019-nCoV) outbreak. medRxiv 10.1101/2020.02.09.20021261.

19. Karako K et al. (2020) Analysis of COVID-19 infection spread in Japan based on stochastic transition model. Bioscience Trends 14, 134-138.

20. Zhang J et al . (2020) Changes in contact patterns shape the dynamics of the COVID19 outbreak in China. Science 368, 1481-1486 
medRxiv preprint doi: https://doi.org/10.1101/2020.11.23.20237404; this version posted December 2, 2020. The copyright holder for this preprint (which was not certified by peer review) is the author/funder, who has granted medRxiv a license to display the preprint in It is made available under a CC-BY-NC-ND 4.0 International license .

21. Zhang Y et al. (2020) Evaluating transmission heterogeneity and super-spreading event of COVID-19 in a metropolis of China. International Journal of Environmental Research and Public Health 17, 3705.

22. Cowling BJ et al. (2020) Impact assessment of non-pharmaceutical interventions against coronavirus disease 2019 and influenza in Hong Kong: an observational study. The Lancet Public Health 5, e279-e288.

23. Yang R, Gui X and Xiong Y (2020) Comparison of clinical characteristics of patients with asymptomatic vs symptomatic coronavirus disease 2019 in Wuhan, China. JAMA Network Open 3, e2010182.

24. Koh WC et al. (2020) What do we know about SARS-CoV-2 transmission? A systematic review and meta-analysis of the secondary attack rate, serial interval, and asymptomatic infection. medRxiv 10.1101/2020.05.21.20108746 .

25. Arons MM et al. (2020) Presymptomatic SARS-CoV-2 infections and transmission in a skilled nursing facility. The New England Journal of Medicine 382, 2081-2090.

26. Zhao H et al. (2020) COVID-19: asymptomatic carrier transmission is an underestimated problem. Epidemiology \& Infection 148: e116.

27. Aguilar JB et al. (2020) A model describing COVID-19 community transmission taking into account asymptomatic carriers and risk mitigation. medRxiv 10.1101/2020.03.18.20037994.

28. Huang L-S et al. (2020) Taking account of asymptomatic infections in modeling the transmission potential of the COVID-19 outbreak on the Diamond Princess cruise ship. medRxiv 10.1101/2020.04.22.20074286.

29. Oster AM et al. (2020) Transmission dynamics by age group in COVID-19 hotspot counties-United States, April-September 2020. MMWR Morbidity and Mortality Weekly Report 69, 1494-1496. 
medRxiv preprint doi: https://doi.org/10.1101/2020.11.23.20237404; this version posted December 2, 2020. The copyright holder for this preprint (which was not certified by peer review) is the author/funder, who has granted medRxiv a license to display the preprint in It is made available under a CC-BY-NC-ND 4.0 International license .

30. Cito F et al. (2020) A COVID-19 hotspot area: activities and epidemiological findings. Microorganisms 8, 1711.

31. Varsavsky T et al. (2020) Detecting COVID-19 infection hotspots in England using large-scale self-reported data from a mobile application. medRxiv $10.1101 / 2020.10 .26 .20219659$.

32. University of Oxford (2020) Coronavirus government response tracker. https://www.bsg.ox.ac.uk/research/research-projects/coronavirus-governmentresponse-tracker. Accessed November 12, 2020.

33. Zou L et al. (2020) SARS-CoV-2 viral load in upper respiratory specimens of infected patients. The New England Journal of Medicine 382, 1177-1179.

34. Ferguson NM et al. (2005) Strategies for containing an emerging influenza pandemic in Southeast Asia. Nature 437(7056): 209-214.

35. Linton NM et al. (2020) Incubation period and other epidemiological characteristics of 2019 novel coronavirus infections with right truncation: a statistical analysis of publicly available case data. Journal of Clinical Medicine 9, 538.

36. Pak D et al. (2020) Age associated coronavirus disease 2019 incubation period: impact on quarantine policy. medRxiv 10.1101/2020.06.27.20141002.

37. Lauer SA et al. (2020) The incubation period of coronavirus disease 2019 (COVID19) from publicly reported confirmed cases: estimation and application. Annals of Internal Medicine 172, 577-582.

38. Heneghan C, Brassey J and Jefferson T (2020) COVID-19: what proportion are asymptomatic? https://www.cebm.net/covid-19/covid-19-what-proportion-areasymptomatic/. Accessed November 12, 2020.

39. Stein RA (2011) Super-spreaders in infectious diseases. International Journal of Infectious Diseases 15, e510-e513. 
medRxiv preprint doi: https://doi.org/10.1101/2020.11.23.20237404; this version posted December 2, 2020. The copyright holder for this preprint (which was not certified by peer review) is the author/funder, who has granted medRxiv a license to display the preprint in It is made available under a CC-BY-NC-ND 4.0 International license

40. Endo A et al. (2020) Estimating the overdispersion in COVID-19 transmission using outbreak sizes outside China. Wellcome Open Research 5, 67. 
medRxiv preprint doi: https://doi.org/10.1101/2020.11.23.20237404; this version posted December 2, 2020. The copyright holder for this preprint (which was not certified by peer review) is the author/funder, who has granted medRxiv a license to display the preprint in It is made available under a CC-BY-NC-ND 4.0 International license .

\section{TABLES}

Table 1. Population parameter estimates

\begin{tabular}{|c|c|c|c|c|}
\hline $\begin{array}{l}\text { Model } \\
\text { parameter }\end{array}$ & Description & Value & $\begin{array}{c}\text { Precision, } \\
\%\end{array}$ & $\begin{array}{c}\text { Variability } \\
\text { between } \\
\text { countries, \% }\end{array}$ \\
\hline$\lambda$ & $\begin{array}{l}\text { Time to becoming infectious } \\
\text { after contracting virus, days }\end{array}$ & 3.43 & 0.187 & None \\
\hline$\alpha$ & $\begin{array}{l}\text { Time to development of } \\
\text { symptoms after becoming } \\
\text { infectious, days }\end{array}$ & 2.57 & 0.472 & None \\
\hline $\mathrm{kq}$ & $\begin{array}{l}\text { Time to starting quarantine } \\
\text { after symptom onset, days }\end{array}$ & 1.00 & Fixed & None \\
\hline Pra & $\begin{array}{l}\text { Proportion of asymptomatic } \\
\text { cases, } \%\end{array}$ & 65.8 & 0.148 & None \\
\hline Pss & $\begin{array}{l}\text { Proportion of super-spreaders, } \\
\%\end{array}$ & 9.55 & 0.544 & None \\
\hline$\beta$ ss & $\begin{array}{l}\text { Transmission rate increase in } \\
\text { super-spreaders }\end{array}$ & 3.11 & 10.8 & 139 \\
\hline $\operatorname{lagD}$ & $\begin{array}{l}\text { Time to the first two infected } \\
\text { persons, days }\end{array}$ & 23.1 & 5.48 & 71 \\
\hline$\beta \operatorname{Max}$ & Maximum infection rate & 0.927 & 5.11 & 67 \\
\hline$\beta \min$ & Minimum daily infection rate & 0.228 & 9.59 & 123 \\
\hline S50_pop & $\begin{array}{l}\text { Stringency index needed to } \\
\text { reach } 50 \% \text { of the maximum } \\
\text { effect on the infection rate }\end{array}$ & 35.3 & 9.33 & 117 \\
\hline
\end{tabular}


medRxiv preprint doi: https://doi.org/10.1101/2020.11.23.20237404; this version posted December 2, 2020. The copyright holder for this preprint (which was not certified by peer review) is the author/funder, who has granted medRxiv a license to display the preprint in It is made available under a CC-BY-NC-ND 4.0 International license .

Table 2. Estimated RR of symptomatic and asymptomatic cases

\begin{tabular}{|l|c|c|c|c|c|c|}
\hline & \multicolumn{3}{|c|}{ Symptomatic cases } & \multicolumn{3}{c|}{ Asymptomatic cases } \\
\hline & Days & $\begin{array}{c}\text { Daily } \\
\text { infection } \\
\text { rate }\end{array}$ & $\begin{array}{c}\text { New } \\
\text { cases, }\end{array}$ & Days & $\begin{array}{c}\text { Daily } \\
\text { infection } \\
\text { rate }\end{array}$ & $\begin{array}{c}\text { New } \\
\text { cases, n }\end{array}$ \\
\hline Pre- & 2.57 & 0.46 & 1.19 & 2.57 & 0.46 & 1.19 \\
symptomatic & & & & & & \\
\hline Symptomatic & 1 & 0.93 & 0.93 & - & - & - \\
\hline Asymptomatic & - & - & - & 10 & 0.46 & 4.64 \\
\hline Total RR & - & - & 2.12 & - & - & 5.83 \\
\hline
\end{tabular}

A 50\% reduction in the infection rate for pre-symptomatic and asymptomatic cases was assumed.

$\mathrm{RR}$, reproduction ratio (number of new cases per subject during their entire infectious period). 
medRxiv preprint doi: https://doi.org/10.1101/2020.11.23.20237404; this version posted December 2, 2020. The copyright holder for this preprint (which was not certified by peer review) is the author/funder, who has granted medRxiv a license to display the preprint in It is made available under a CC-BY-NC-ND 4.0 International license

\section{FIGURES}

Figure 1. Initial COVID-19 transmission model.

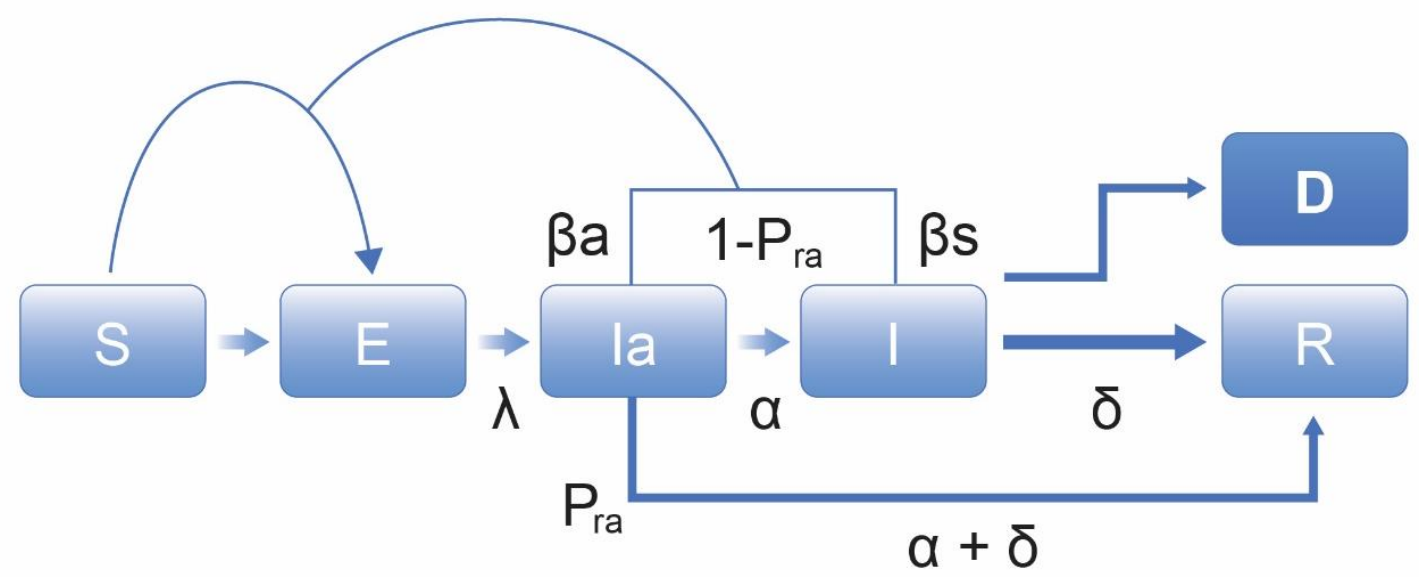

S, susceptible population; E, exposed patients not yet infectious; Ia, infected infectious patients who are asymptomatic; I, infected infectious patients; R, recovered; D, death. $\lambda$, median incubation period; $\alpha$, start of infectious period; $\delta$, duration of infectious period. 
medRxiv preprint doi: https://doi.org/10.1101/2020.11.23.20237404; this version posted December 2, 2020. The copyright holder for this preprint (which was not certified by peer review) is the author/funder, who has granted medRxiv a license to display the preprint in

It is made available under a CC-BY-NC-ND 4.0 International license

Figure 2. Stringency index for mitigation strength scoring.

\begin{tabular}{|c|c|c|c|}
\hline Indicator & $\mathbf{N}_{\mathrm{j}}$ & Targeted/General? & \multirow{2}{*}{$\begin{array}{l}\text { Additional weight for a policy of general scope is defined in relation to } \\
\text { the number of ordinal points in the eight indicators that have the } \\
\text { targeted/general flags: }\end{array}$} \\
\hline School closing & $3(0,1,2,3)$ & Yes & \\
\hline Workplace closing & $3(0,1,2,3)$ & Yes & $\mathrm{w}=\frac{1}{8} \sum \frac{1}{(N+1)} \approx 0.29$ \\
\hline Cancel public events & $2(0,1,2)$ & Yes & \\
\hline Restrictions on gatherings & $4(0,1,2,3,4)$ & Yes & \\
\hline Close public transport & $2(0,1,2)$ & Yes & \\
\hline Stay at home requirements & $3(0,1,2,3)$ & Yes & \\
\hline Restrictions on internal movement & $2(0,1,2)$ & Yes & ( \\
\hline International travel controls & $4(0,1,2,3,4)$ & No & $I_{j}=100\left(\mathrm{C}_{j} \quad N_{j}\right.$ \\
\hline Public information campaigns & $2(0,1,2)$ & Yes & $S I_{L}=\frac{1}{7}\left(I_{C 1}+I_{C 2}+\operatorname{Max}\left(I_{3}, I_{4}\right)+I_{C 5}+\operatorname{Max}\left(I_{6}, I_{7}\right)+I_{C 8}+I_{H 1}\right)$ \\
\hline
\end{tabular}

$C_{j}$, ordinal value of the indicator; $G_{j}$, general value; $I_{j}$, subindex; $N_{j}$, maximum value of the indicator. 
medRxiv preprint doi: https://doi.org/10.1101/2020.11.23.20237404; this version posted December 2, 2020. The copyright holder for this preprint (which was not certified by peer review) is the author/funder, who has granted medRxiv a license to display the preprint in It is made available under a CC-BY-NC-ND 4.0 International license

Figure 3. Relationship between the stringency index and the reproduction ratio.

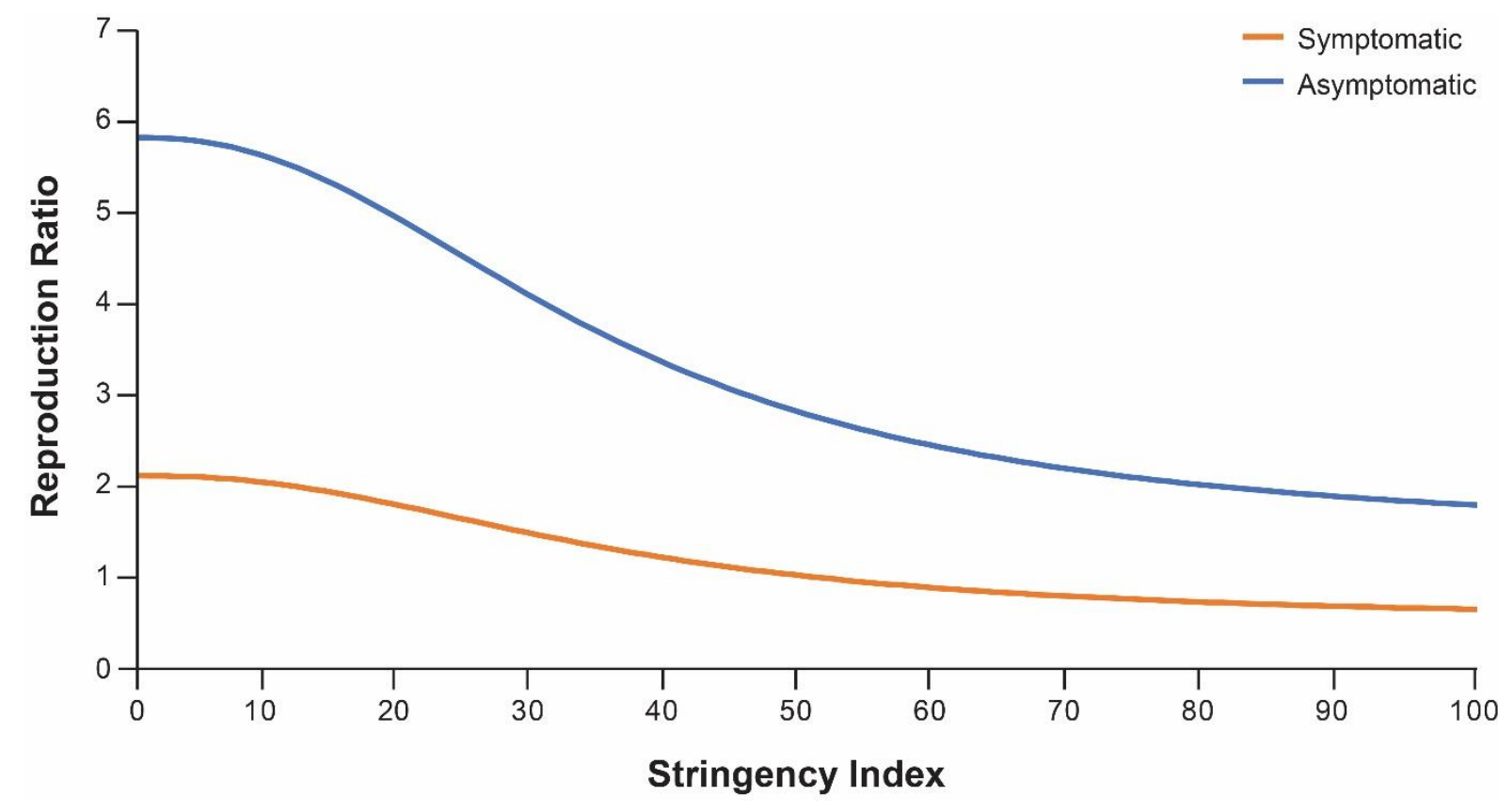


medRxiv preprint doi: https://doi.org/10.1101/2020.11.23.20237404; this version posted December 2, 2020. The copyright holder for this preprint (which was not certified by peer review) is the author/funder, who has granted medRxiv a license to display the preprint in It is made available under a CC-BY-NC-ND 4.0 International license

Figure 4. Data fitting for representative countries. Blue dots represent observed data; black lines represent model prediction. See online supplementary appendix for all countries.

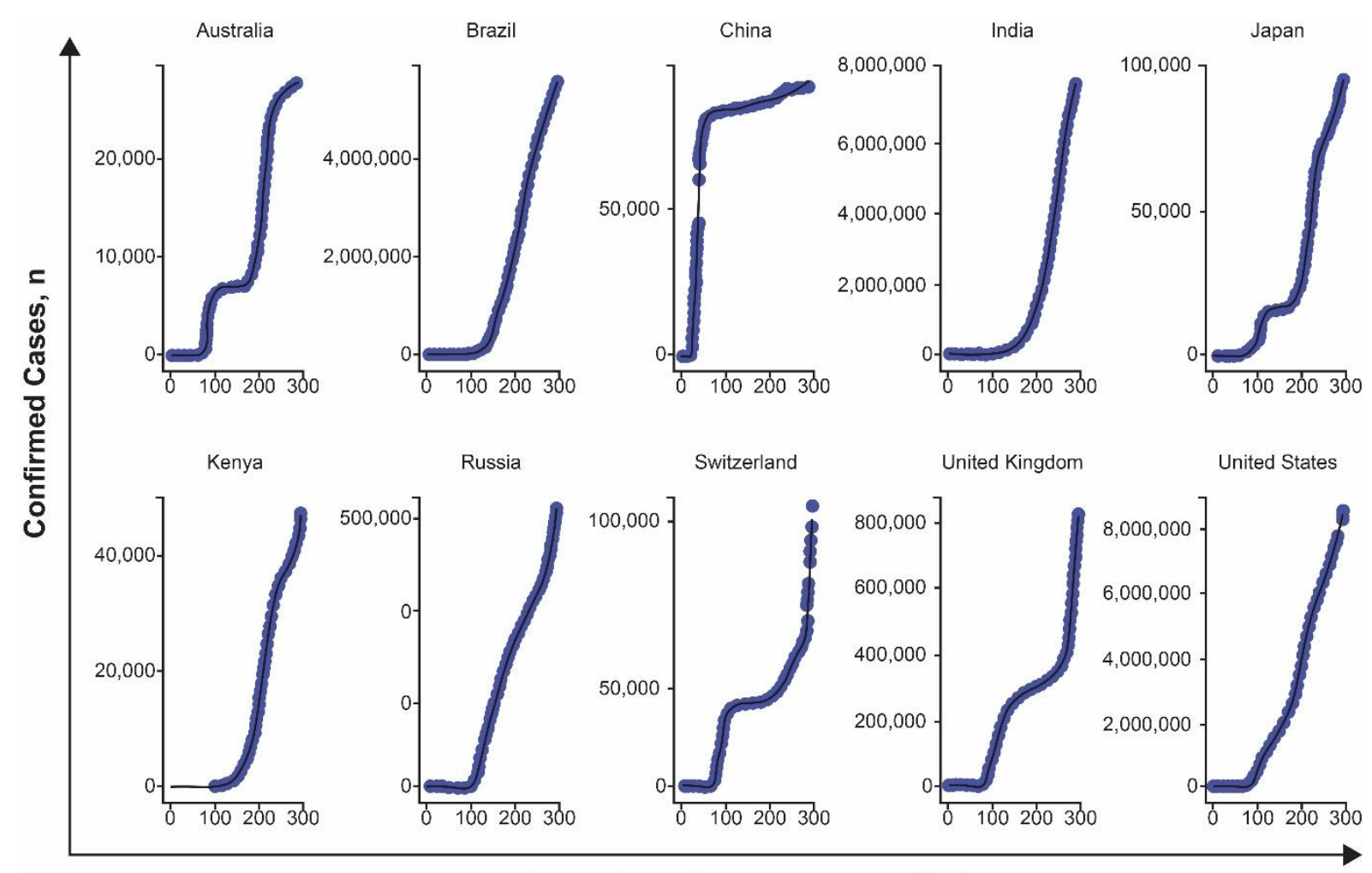

Time, days (from 1 January 2020) 
medRxiv preprint doi: https://doi.org/10.1101/2020.11.23.20237404; this version posted December 2, 2020. The copyright holder for this preprint (which was not certified by peer review) is the author/funder, who has granted medRxiv a license to display the preprint in It is made available under a CC-BY-NC-ND 4.0 International license .

Figure 5. Simulation results by country. Black dots indicate observed data; blue shaded area indicates simulated time course for each scenario with low viral spreading; red shaded area indicates simulated time course for each scenario with high viral spreading; grey rectangles highlight the forecasted period. 
medRxiv preprint doi: https://doi.org/10.1101/2020.11.23.20237404; this version posted December 2, 2020. The copyright holder for this preprint (which was not certified by peer review) is the author/funder, who has granted medRxiv a license to display the preprint in It is made available under a CC-BY-NC-ND 4.0 International license .
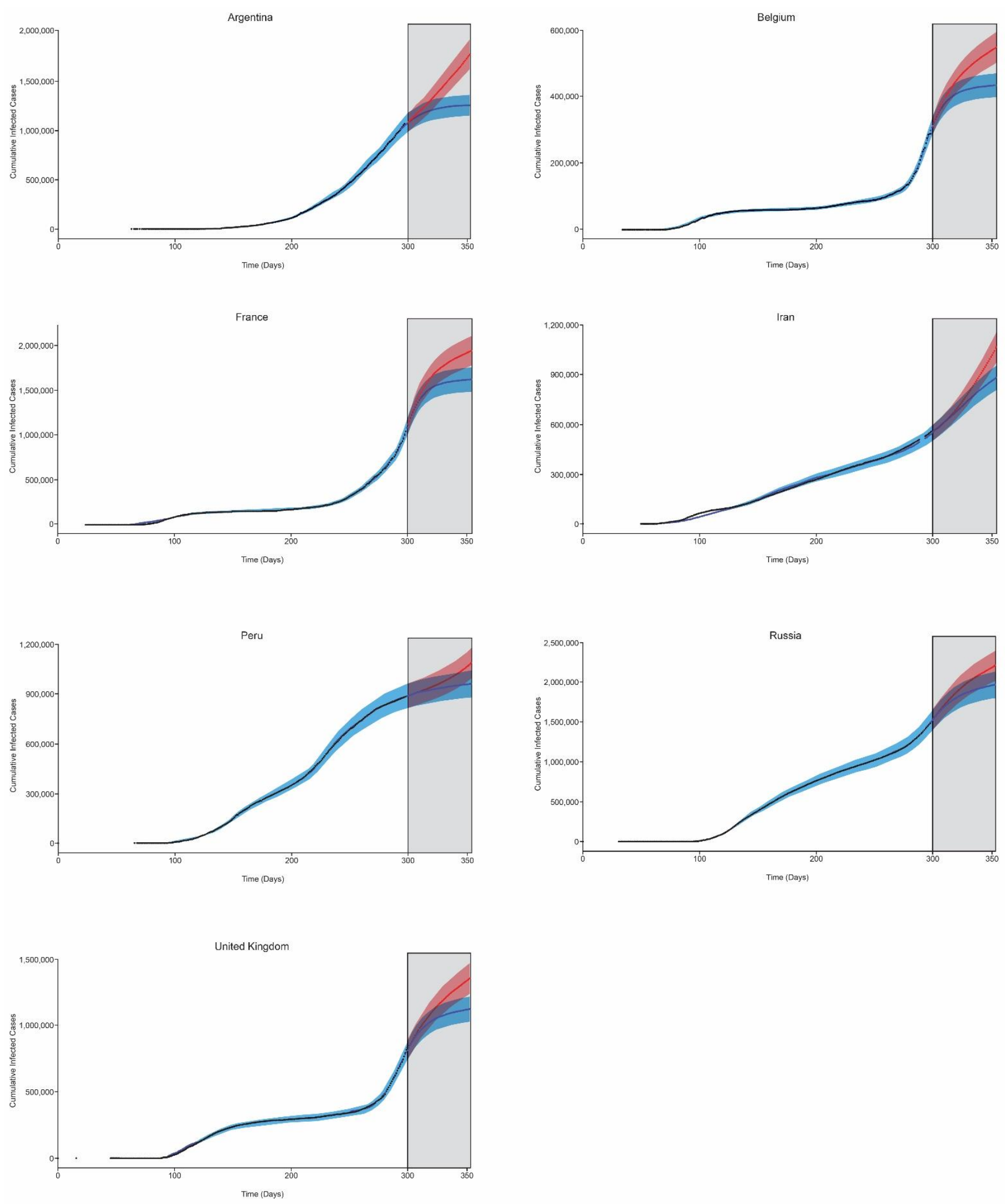